\title{
THE STATUTORY DEFINITION OF GIFT VALUE AS A "FILTER" FOR EFFECTIVE STATE POLICY IN THE PUBLIC SERVICE
}

\author{
Tetiana Kolomoets ${ }^{1}$, Nataliia Halitsyna ${ }^{2}$, Serhii Kushnir ${ }^{3}$
}

\begin{abstract}
The paper substantiates the importance of standardization of gift's "value feature" for a public person as a reliable "filter" for eliminating threats for effective implementation of the state policy in the public service. Methodology. The analysis of regulatory and law enforcement experience of different countries allowed distinguishing three basic regulatory models of "gift relations" in the public service - prohibitive, permissive, and mixed. Clarification of the essence of each of them led to the conclusion on the expediency to choose the mixed model as an optimal alternative for an effective counteraction to the unlawful, non-purpose use of gift resource in the public service under the conditions of modern reformation state-building and law-enforcement processes. This model due to a simultaneous regulation of the principles of "prohibitive gift" relations, "permissive gift" relations envisages determination of the limits for possible reception of other gifts by public servants. It ensures elimination of the prerequisites as for waking "gift relations" in the public service, so for unreasonable use of the gift as a source for enrichment, encouragement means, and "instrument for influence" on the professional official activity of a public servant. Results. A unique character of the gift in the public-official relations is caused, first of all, by its trifling "symbolic" value. Due to this fact it can be considered as a "symbolic manifestation" of respect, gratitude to a public servant for his competent, honourable, lawful professional official activity. Its symbolic "value feature" is its central feature that causes the need for its obligatory complete regulatory determination. On the basis of the comparative legal analysis of rule-making and law-enforcement experience of different countries, a number of basic approaches to the definition of "value feature" of a gift are distinguished (in a completely determined amount, in a multiple of the guaranteed rates established by the state, in a multiple to the salary of a public servant, in a generalized form without any quantitative indicators and with the list of possible external forms of gift's manifestation etc.), and it is justified the feasibility of its binding to a certain number of the national currency ("solid", "constant" indicator). Practical implications. Standardisation of this gift feature along with others which carry out an additional role (frequency of reception and source) should be at the level of the basic legislative act, which consolidates principles of "gift relations" in the sphere of public service in its entirety. Taking into account the importance of this gift feature, any sub-legislative "alternative" in relation to the determination of gift value can't exist eliminating the grounds for a controversial nature of regulation of relevant relations. Value/originality. It will help to unify the regulatory standards for using gift's resource in the public service as a whole, regulatory "filtering" effectiveness of the implementation of public policy in the sphere of public service as a whole.
\end{abstract}

Key words: public service, public servant, model, gift, statutory regulation, value, feature, proposals, filter, legislation.

JEL Classification: D31, E24, J31, K00

\section{Introduction}

Effective implementation of the state policy in the sphere of public service depends on a range of factors including "quality" of statutory regulation of its principles. In addition, it is important not only to consider positive domestic and foreign experiences of the functioning of institutions, which directly generate content of the public service but also of those ones, which play a role of "protectors" of its non-effective functioning. Special restrictions for public servants have been occupying a prominent position and keep it now among protectors and non-compliance with which are considered as an unlawful act (in different forms of its manifestation) and stipulates a legal responsibility.

\footnotetext{
Corresponding author:

${ }^{1}$ Zaporizhzhia National University, Ukraine.

E-mail: t_deputy@ukr.net

${ }^{2}$ Berdiansk Institute of Public and Municipal Administration of Classic Private University, Ukraine.

E-mail: galicina.natalia73@gmail.com

${ }^{3}$ Zaporizhzhia National University, Ukraine.

E-mail: prorektor.znu@gmail.com
} 
Traditionally, special restrictions for public servants are regarded to be a type of anticorruption measures and their non-observance is a violation of corruption content (with the consolidation of various formulations, type diversity in the legislation of different countries). For this reason, determining the main priorities of state policy in the sphere of public service, it is statutory consolidated not only the principles of introduction, disciplinary responsibility for public servants but also "filters" of anticorruption policy in order to eliminate the threats for an effective implementation of the state policy in the sphere of public service at large. Analysis of the legislation of different states indicates that special restrictions for public servants are paid a lot of attention to (either at the level of a component of the main legislative act on public service or in individual legislative act of anticorruption nature), and the restriction for public servants concerning gifts reception is marked among their entire diversity. It is worth mentioning that gifts always "accompany" public official relations in different countries, however, their influence degree on these relations have differed in various countries that mainly caused by the specific nature of the chosen model for regulating relevant relations. Prohibition, restriction, and permission are the most widespread methods for regulating relations, which are "ground" of official regulatory "gift" model in public-service sphere in different countries, practical realization of which taking into account historical, national peculiarities of rulemaking and law enforcement led to the different effectiveness degree of the state policy in the public service. It is important not only to choose one of the basic "gift statutory models" for regulating relations in the public service but also to introduce the "filters" putting in detail the principles of use of their resource, which would ensure an effective implementation of "gift" policy as an integral part of the state policy in the public service. That sort of "statutory filters" is traditionally considered the definition of gift source, the frequency of its receiving, type diversity of a gift etc. In addition, gift value should occupy a special place among them as it can lead to "gift quality" and degree of its influence on a public servant and his professional activities. Regulatory determination of a gift facilitates resolving the issue on the delimitation of a gift from improper advantage, as well as classification of unlawful acts, which can be performed by a public servant that in its turn envisages different legal effects for the latter.

In the context of a radical reconsideration of the state policy fundamentals in the sphere of public service, anti-corruption policy, searching for effective means for prevention of unlawful acts of corruption nature commissioned by public servants negatively influences the functioning of the public service as a whole, activation of regulatory and draft activities aimed at elaborating and adopting new regulatory legal acts geared towards the regulation of relevant relations, the issue of "regulatory filtering" of restrictions of public servants takes on particular importance. It is very important to analyse rulemaking and law-enforcement experience of different countries from the perspective of gift value for a public servant in order to clarify what model is the most perfect in content and the most effective in exercise. Analysis of available provision of subject scope is vital in order to form a reliable scientific basis for understanding the phenomenon of gift value for a modern rulemaking process, which provides for complying with the principle of scientific character during the latter one. It allows specifying a range of problematic issues directly connected with regulatory determinacy of gift value for public servants, formulating proposals for the building of optimal regulatory "cost model" to settle relevant relations as an integral component of "gift" policy in the public service. All these issues are the purpose of the article. When writing the paper, we have used as general methods of scientific knowledge, as well as special, which allowed distinguishing the cost of a gift among all features diversity of the latter, justifying the expediency of its normative definition, formulating specific proposals for its statutory regulation taking into account the results of comparative legal studies of the experience of rulemaking and law enforcement of different countries. The basis was scientific, journalistic, regulatory sources. However, there are no research papers directly devoted to the issues of "value feature" of the gift for a public servant. There are either papers devoted to the range of problems towards special restrictions for public servants in general (Vylloriia, Synnestrom, Bertok, 2010) or restrictions on gifts receptions, however without focusing on gifts value (Kolomoiets, Verlos, Pyrozhkova, 2018), or experience of certain countries regarding regulating issues concerning gifts restrictions for public servants (Zimneva, Chumakova, 2015), or general analysis of determination of gift value for public servants, but using selective approach to characteristic of the experience of each country and separation of regulatory legal acts which fix gifts value (Suslova, Fluri, Badrak, 2017). Overall, this leads to a simplified approach to clarifying a resource of "values feature" of the gift for a public servant and its regulatory determinacy as a "filter" for effective implementation of the state policy in the sphere of public service.

\section{2. "Basic" regulatory models of "public relations" in the public service}

Analysis of foreign experiences shows that in general, there are three "basic" regulatory models, which are consolidated as follows: prohibitive, permissive, mixed. The first, prohibitive, model envisages a total prohibition for public servants to receive any kind of gifts and in such a case gift value is not important. So, "gift feature" is not consolidated at the regulatory level for such a kind of 
model because prohibition makes any actions with gifts on the part of public servants impossible. For example, Argentina provides the prohibition on gifts reception by public servants and criminal liability for prohibition violation (Suslova, Fluri, Badrak, 2017). "Prohibitive" model of "gift" relations is also consolidated in Norwegian legislation indicating that prohibition is caused by "elimination of moral obligation for donator to create special conditions for public servants" as well as in the legislation of Lithuania and Czech Republic to guarantee "incorruptibility" of public servants (Suslova, Fluri, Badrak, 2017). In particular, public servants don't have the right to receive gifts in Great Britain, Germany, and Spain. The latter legislation states that "...must reject any gifts..., which can put exercise of servant's official functions in dependence on certain conditions" (Vylloriia, Synnestrom, Bertok, 2010). At the same time, along with the prohibition on gifts reception, the legislator clearly specifies the duty of public servants to declare their income, which serves as an additional regulatory "filter" for monitoring public servants regarding their compliance with "gift" legislation. Such a strict model, undoubtedly, "simplifies" the regulation of relations in the public service, ensures their determinacy and controllability. However, as the analysis of available scientific sources shows, gifts still "accompany" the public service relationship, including by virtue of "traditions" in relation to the exchange of souvenirs, signs (manifestations) of hospitality, loyalty, courtesy, etc. The diversity of relations that mediate professional activities of public servants, the subjects of such relationships, envisages the possibility of preconditions for "gift" relationships that can negatively affect the staffing of the public service as a whole, and serve as the basis for "activating" "gift" relationships in the public service, which also negatively affects the latter. It raises the issue whether it is necessary, taking into account the above mentioned, to introduce a prohibitive model of "gift" relations in the sphere of public service or will it be effective during the implementation?

Permissive model of "gift" relations provides lack of any indications towards the prohibition of gifts reception by public servants and hence indications towards their value that is quite logical. In particular, the legislation of Japan doesn't have any restrictions or prohibitions on gifts reception by public servants (Suslova, Fluri, Badrak, 2017) as well as in Taiwan (Suslova, Fluri, Badrak, 2017). However, permission to receive gifts doesn't mean uncontrolled nature of particular relations. By giving the right to public servants to receive a gift, the legislator simultaneously introduces the obligation for public servants to declare it. If there are no reasons to suggest about bringing of public servants to legal liability for violation of "gift" legislation in the part of compliance (non-compliance) with prohibitions or restrictions in relation with their lack. At the same time, there is a possibility to bring public servants to responsibility for non-compliance with requirements concerning the declaration of received gifts. In practice, in this case, the declaration legislation plays a role of a specific element of "gift" legislation in the sphere of public service, "filter" of state policy effectiveness in the public service.

It is not expedient to justify such a "simplified" comprehension of the role and significance of a gift in the public-official relations (with the lack of any standards for conduct). Gifts reception of any value from any persons in any number by a person authorized to exercise public authoritative powers creates a certain threat to the impartiality, transparency, objectivity, and legality of the activity of such a person. A gift can play a role not to show respect, appreciation, to press a person, sources of enrichment of the latter, etc. Under such conditions, it is quite possible to use gift resource, not for its target purpose. It is not enough to rely on the obligation to declare all received gifts of public servants taking into account the fact that degree of compliance with the legislative requirements in the part of public servants' declarations (under different conditions, circumstances) can differ. "Gift" relations in the sphere of public service, taking into account the features of the latter, should be regulated in terms of determining the behaviour patterns of their subjects in order to ensure the effectiveness of the implementation of state policy in the public service.

A mixed model is the most widespread regulatory model of "gift" relations in the sphere of public service, which simultaneously provides prohibition, permission, and restrictions on gifts reception by public servants and its "value feature" obtains sense in relation to the determination of the abovementioned restrictions. Mixed type is the most typical regulatory model for most countries. For example, the legislation of Mexico stipulates that delegates and their closest relatives are forbidden to receive "any commercial papers, real estates, proprietary rights or cession of rights on any kind, regardless of their value, independently or by virtue of other people from any persons, corporations, establishments whose interests touch upon the issue under consideration or if it can lead to conflict of interests" (Suslova, Fluri, Badrak, 2017). At the same time, other gifts can be accepted, the most important thing is that they should not exceed the salary of a person up ten times and they must be declared. In the USA, it is prohibited to receive gifts that are directly related to the professional activities of a person and "gifts in cash". At the same time, it is allowable to receive gifts from relatives and even "gifts on the basis of personal relations", gifts received during official events (however, according to certain requirements for their use). In relation to other gifts, their reception depends on complying with some requirements including their value (Kolomoiets, 2018). The similar model is also consolidated in the legislation of Ukraine as follows: 
the prohibition covers the gifts that are directly related to the official activity of a person, as well as received from subordinates, and permissions are for gifts from close relatives and publicly available bonuses, discounts, privileges. The same models are introduced by other countries, however with some details for the grounds for reception of permissive gifts (for example, in Ireland, public servants can accept gifts from relatives, close persons on "special occasions"), "restrictive" gifts (for example, in Australia there is delimitation of gifts from official and non-official sources, in South Africa there is specification on gifts' reception during a year from one source) (Suslova, Fluri, Badrak, 2017). It is a mixed model that allows identifying "polar" conduct parameters of subjects of "gift" relations in the sphere of public service as follows: what is generally forbidden ("taboo"), what is generally allowed ("absolute plus"). In addition, "gift" relations between these "polar" ("diametrically opposite") parameters are also normalized by virtue of established frontiers ("boundaries", "limits") that provides an opportunity to mark "gifts which are restricted in their reception", socalled gifts "limited in reception". What does play a role of such boundaries? Defining prohibitions and permissions on gifts reception, the legislator specifies subjects-donors in practice. In the first case, these are persons who enter in relations with a public servant, which are connected with a professional activity of the latter, or those who have relations based on subordination with them. In the second case, these are close persons of a public servant and persons who entry into relations with the public servant for whom his special status is the most important thing in general. In other words, in advance, the legislator determines the range of potential subjects of "gift" relations with the participation of public servant and defines subjective boundaries regarding relations with "restrictive gifts". Decided upon the subjects of "gift" relations with regard to "polar" and "limited" components, the gift itself should be subject to standardisation with a focus on its features. In this context, normative consolidation of gift definition takes on particular importance with the purpose of providing harmonisation of law-enforcement in the mentioned sphere. As a rule, the definition of a gift is formulated through enumerating its possible external forms of manifestations. For example, in the USA legislation, the gift for a public servant is considered as a "money reward", non-act or other actions or things that can have a monetary expression", "services, payment of education, transport, local travel, meals either in a natural form or in another one" (Kolomoiets, 2018). Almost similar definitions can be found in the legislation of Ukraine, Brazil. In general, there are several trends in the normative consolidation of a gift for a public servant a narrowed and extended list of possible external forms of its existence. However, it is obligatory to indicate that it is received not for the unlawful conduct of a relevant person, but it is a reaction to the lawful acts of the latter. This gift feature distinguishes it from improper advantage. At the same time, as a reaction to the lawful actions of a public servant, the gift is not a payment for such an activity, therefore, it cannot be such that it is provided on a regular (periodic) basis, be proportionate to the efforts made by the public servant in the course of his professional activity, cannot play the role of incentive for the mandatory provision of a gift to a public servant in the future. In other words, the gift, according to its recourse, is a "symbolic" manifestation of respect, appreciation of a public servant for his lawful effective, fruitful activity according to its recourse. The nominal value of the gift, among other things, is intended to define this "symbolic" nature. The gift for a public servant is not his salary, neither incentive nor means of influence, including an illegal one, on professional activity of a public servant, not a source of his enrichment, but only "symbolic" gratitude, respect to the public servant. These gifts shouldn't be mistakenly identified with treasured gifts, which according to the legislation of many countries, are recognised as the incentives for essential achievements in professional official activities of a public servant (for example, the legislation of the USA, Ukraine, China), as well as separate from "official" ("business") gifts, which can be accepted by public servants, as representatives of the state, community, during official events. "Value feature" in relation to "official" ("business") gifts are not important as they are presented for a state, territorial community, according to statutory established procedure, and for the government or municipal ownership of the state and their "direct contact" with public servants are temporary and caused by exercise of his special legal status. Analysis of different foreign legislations shows that among all diversity of features of "restrictive" gifts, gifts' value plays the most important thing and, as a rule, is the first in the list. And this fact justified as gift value significantly influences the whole resource of the latter causing influence of the gift on a public servant. In public-official relation, the gift plays a role of means of respect, gratitude to a public servant for his rightful professional activity. This fact raises profound attention to the definition of gift value and its regulatory consolidation. If this is a symbolic gratitude, respect manifestation, so they can't be too large and, accordingly "symbolic", "nominal", "metaphoric", provoke the feeling of return of the public servant or play incentive role for a similar obligatory gift reception in the future, desire for a personal enrichment by virtue of gifts. This stipulates a balance of a small value (symbolic nature) of the gift and its slight (symbolic) influence on a public servant in the form of manifestation of respect, gratitude and moral satisfaction. The value that should be absolutely determined at the legislative level can provide the implementation of a relevant real resource of the gift in public-professional relations. 
The use of value definition in this case like "that conforms to common norms" (for example, in the legislation of Korea), "corresponds to the universally recognized concept of hospitality" (for example, in the legislation in Ukraine), "under common traditions of communication", "... in the context of courtesy manifestation" (for example, in the legislation of Spain) can be only additional, however it is not advisable, as stipulates their subjective manifestation when defining and applying, practice variety of arbitrary resolution of the same issue by different persons, or by one person of different issues of "gift" content. This issue can be regulated by virtues of normative consolidation of a specific gift value as a "filter" of permissive nature for a public servant.

\section{Regulatory consolidation of gift value for a public servant in different countries}

In general, the legislator has followed this advice, but there is a distinct nature of the approach to the direct consolidation of the gift value for a public servant in different countries. For example, in Australia gift value from non-official source can't exceed two hundred Australian dollars and five hundred Australian dollars for the gift from official source, in Canada - two hundred Canadian dollars, in Ireland - five hundred pounds, in Korea - one hundred thousand wons, in Russia - three thousand roubles, in Singapore - fifty Singapore dollars (Bykeev, 2013), in Brazil - one hundred reals (Vasyleva, 2015), in the USA - twenty dollars for one donator in every particular case upon condition that the total value of all gifts from one source doesn't exceed fifty US dollars during a year, and for congressmen and senators three hundred and two hundred US dollars respectively (Bykeev, 2013). For the majority of European countries, gift value is one hundred euro, but in Denmark, the value is equal to one hundred and forty euros (Bonsing, Langsted, 2013). In Great Britain, the gift value for persons, who hold appointive position, can't exceed one hundred and forty pounds (Vylloriia, Synnestrom, Bertok, 2010). There are countries, the legislation of which consolidates gift value for public servants not in a "solid amount" but in "tying" to a particular regulatory determined amount. For example, in Ukraine, the value of "restrictive" gift for reception by a public servant shouldn't exceed one minimum cost of living for an able-bodied person established on the date of gift reception. At the same time, the value of all gifts received by a public servant within one year from one source may not be greater than two minimum costs of living established for an able-bodied person on the first of January of the year, in which the gifts were received (Kolomoiets, Verlos, Pyrozhkova, 2018). The definition seems somewhat large and raising some questions on the adjustment of the coefficients for determining the value of one and a set of gifts, taking into account the potential possibility, considering sufficient regulatory permitted grounds, adjustment of the size of the subsistence minimum during the calendar year. The experience of Mexico is also interesting, as already mentioned, according to its legislation the value of gifts "cannot exceed ten times the salary of the person receiving them" (Suslova, Fluri, Badrak, 2017). There is a question, how one can clarify the issue of compliance with the requirements of "gift" legislation by a public servant in a case of change of his salary amount during the year in practice and, even more so, if such a change is repeated? Is it possible to hope for the effectiveness of theregulatoryconsolidation of giftvalueinsucha "format" as a "filter" for the implementation of public policy in the sphere of public service? The same question is raised in the case of a regulatory consolidation of the list of prohibitive (for example, in the legislation of Mexico) or permissive (for example, in the legislation of China) forms of the external gift manifestation without an indication on their "maximum" value for a possible reception by civil servants. In particular, the legislation of China stipulates that public servants are forbidden to receive any gifts except books. As a consequence, analysis of law-enforcement practice illustrates frequent cases of the reception of unique books editions with covers made with the use of precious metals and stones by such persons. Statutory consolidation of gifts "tying" for public servants exclusively to the periodicity of their reception is not justified in the context of providing the effectiveness of the implementation of government policy in the public service that in its turn can provoke clarifying the issue of their number. For example, the legislation of Ukraine and South Africa has indications on the availability of multiple gifts reception by public servants during a calendar year. In addition, a specification of legal frameworks can be connected with the identification of gift resource. In particular, the provision "from one source" is consolidated in the legislation of Ukraine, South Africa, "with an indication of the information about a donator" - in the legislation of Italy, "from non-official source" - in the legislation of Australia. Without dispute, taking into account the specifics of the gift itself, which cannot be received permanently or periodically, it is important to consolidate quantitative restrictions towards gifts reception for public servants in terms of legislation. In order to eliminate threats of "gift influence" on a public servant, his professional activity on the part of a person (group), it is essential to provide for regulations on the minimisation (as a rule, no more than two) "gift" contacts of a public servant. However, it should be kept in mind that one "gift" contact with the gift which, due to its value, can influence a public servant more powerful than frequent "gift contacts" with the presence of low cost. Thus, under any conditions, the gift value has to play a key role when defining and consolidating principles "gift relations" in the public service. An indication of a minimum frequency of gift reception 
and determination of its source will additionally consolidate a "symbolic nature" of the gift. And even the gift, which is repeatedly received by a public servant during a year from the same person, can't significantly influence his professional official activity due to its low cost. For this reason, when formulating the principles of "gift" relations in the public service concerning so-called "limited gifts", first of all, it is necessary to fix their maximum authorised value and then the restrictions on the frequency and source of their reception. The lack of a clear, statutory defined "value" feature of the gift causes models variety of "gift" relations with the participation of public servants that cannot be justified in any case. Only a total regulatory definition of gift value, which can be received by a public servant, allows guarantying transparency, monitoring of "gift" relations in the sphere of public service in whole. How "value feature" of a gift should be defined? An answer to this question should be found simultaneously with an emphasis on the specific nature of the national rule-making. If in the state statutory instruments, which regulate the relations in the public-legal sphere, are aimed at taking into account "strong" figures (particular for countries with a high level of economic development), therefore, "gift" relations should be regulated using the same figures. If the regulatory activity of the state is connected with a dominant use of "minimum guaranteed value" (as a rule, it is particular for countries in the transitional period of their development, pivotal modification of functioning vectors etc.), so it is quite possible to consolidate "tying in" of the gift value for public servants to such measures at the regulatory level. Any options of a statutory definition of gift value should be aimed at its maximum minimization that it plays exclusively the role of manifestation of "symbolic" respect, gratitude to a public servant, and eliminates any expression of interest in it on the part of the public servant. As well as the definition of the gift, subject of its reception and donation, the value of gift (or particular "solid" amount in the national currency, or "tying in" to the minimal government-guaranteed amount, which can't change during a calendar year) should be regulatory consolidated in the basic legal act, which secure the models of "gift relations" in the public sphere. The definition of a "value" feature of a gift should be of such nature as to make impossible any unreasonable interpretation on the part of any subject of publicofficial legal relationships, and therefore, it should be absolute. The issue of the need to amend statutory stipulated regulation regarding "value" feature of a gift in the case of changes in the economic development of the state does not have particular urgency as the value of the gift must not be in line with economic processes in the state in any way. "Symbolic" value rate should keep its position under any conditions, which is confirmed by experiences of the countries, the legislation of which have been consolidating "value" feature of the gift for public servants in a particular amount of the national currency for a long time. It is quite logical to raise the question what can be the value of a gift for a public servant? Offering a suggestion to standardise the specific amount of gift value for a public servant in the form of a constant "solid" indicator, it would be worth specifying the proposal. What estimation should be a base for the definition of "value feature" for gifts which are regulatory restricted? Unfortunately, analysis of "gift practice" in most countries doesn't allow determining approaches' solidarity of developers of legislative acts. At the same time, basically, value indicators of gifts for a public servant, which are consolidated in the current "gift law" in the sphere of public service in different countries, are from 10 to 45 per cent of their average salary. It would be perfectly possible to borrow the same practice and to develop unified legal standards for "gift relations" regarding the value of a gift for a public servant. To determine the "value" of the gift, it would be quite possible to propose the following algorithm of action. Developers of a legislative act that fixes the principles of "gift relations" in the public service based on the amount of the average salary (without taking into account premiums, supplements, and possible extra payments) of a public servant in the country and determine "value feature" of the gift in the amount of ten percent of the average salary of a public servant in the national currency units. "Value feature" of a particular gift is consolidated as a "solid indicator" in a relevant legislative act and is not subject to improvement as under any conditions the gift keeps the role of manifestation of "symbolic" respect, gratitude despite inflationary processes and change of average salary rate of a public servant. The most important thing is that statutory fixed approach to the definition of the "value" of the gift is consistent with the general tendencies of lawmaking and law-enforcement in the sphere of public service, public-tort sphere for a violation of public service law in order to ensure a high "quality" of legal framework for the implementation of state policy in the sphere of public service as a whole.

\section{Conclusions}

Guarantee of the effective implementation of state policy in the sphere of public service is directly related to the "quality" of statutory consolidation of its principles also including those that are focused on eliminating threats to such efficiency. Violations of a corruption nature along with breach of special restrictions by public servants, including restrictions on gifts reception, take a prominent place among such sort of principles. In spite of the standardisation of "gift relations" in different countries with choosing the basic model of such relations (prohibitive, permissive, mixed), in practice, the gifts "accompany" publicservice relations adversely affecting the public service as 
a whole. Practical inexpediency of the implementation of "polar" regulatory models for a settlement of "gift" relations in the sphere of public service (prohibitive and permissive), due to which their promotion takes place, or excessive use of gift's resource with the permissive modification of its intended purpose, causes choosing mixed model as an optimum alternative. The latter, thanks to the simultaneous regulatory consolidation of the principles of "permissive" and "prohibitive" "gift" relations, stipulates the fixation of the behaviour of public servants in relation to other (so-called "restricted for receiving") gifts, which promotes the unshadowing of all "gift" relationships in the public service sector. In the definition of diametrically opposed, in content, behaviour models for public servants regarding gifts reception, namely prohibition and permission, the legislator actually determines the subject line for the gifts "restricted for receiving" as one of the standard "filters" of "gift policy" as a whole. The resource of the gift itself is important, the use of which can affect a public servant, his professional activity in different ways, in different extent. In order to prevent such an impact, it is expedient to fix the maximum value of a gift for public servants ("value feature" of a gift), which will create a "symbolic character" of a gift for a public servant, the role of manifestation of "symbolic" respect, gratitude for his professional bona fide, qualitative, lawful official activity. Absolute determination of the "value feature" of a gift (in the form of a clearly defined number of the national currency units as the most alternative option) without the use of any estimative factors will contribute to unifying the practice of applying legislation on this issue, eliminating any subjective manifestations of its unreasonable interpretation. The statutory regulation of the "value feature" of a gift (as its primary feature) will serve as a reliable "filter" (in combination with limits on the frequency and sources) for an effective elimination of the risks for the implementation of "gift policy" in the sphere of public service and national policy in the public service as a whole.

\section{References:}

Villoriia, M., Synnestrom, S., Bertok, Ya. (2010). Etyka derzhavnoi sluzhby: zapobihannia konfliktu interesiv ta vymohy do zakonodavstva [Ethics of the public service: prevention of conflict of interest and requirements to the legislation]. Kyiv: Center for Adaptation of the Civil Service to the Standards of the European Union. (in Ukrainian) Kolomoiets, T., Verlos, N., Pyrozhkova, Y. (2018). A gift for a public servant - a manifestation of respect, reward or a means of unlawful influence. Baltic Journal of Economic Studies, 4(1), 227-234. doi: 10.30525/2256-0742/20184-1-227-234

Zimneva, S., Chumakova, A. (2015). Legal regulation of civil servants in Russia and Germany receiving gifts. Russian Law Journal, III(3), 142-151.

Suslova, I., Fluri, F., Badrak, V. (2017). Parlamentska etyka v Ukraini. Realii, potreby, perspektyvy [Parliament ethics in Ukraine. Realia, needs, perspectives]. Kyiv: Center for Adaptation of the Civil Service to the Standards of the European Union.

Kolomoiets, T. O. (2018). Obmezhennia shchodo oderzhannia podarunkiv osobamy, upovnovazhenymy na vykonannia funktsii derzhavy abo mistsevoho samovriaduvannia za zakonodavstvom Ukrainy: naukovopraktychnyi komentar [Restrictions on gifts reception by persons empowered to implement the functions of state or local self-government under the law of Ukraine: scientific and practical commentary]. Zaporizhzhia: Helvetika. (in Ukrainian)

Bikeev, I. I. (2013). Problemy otgranicheniya vzyatki ot podarka v Rossii i za rubezhom: praktika i tendentsii [Problems of delimitation of bribe from a gift in Russia and abroad: practice and tendencies]. Aktualnye problemy ekonomiki i prava, 1, 245-249.

Vasileva, V. M. (2015). Regulirovanie konflikta interesov na gosudarstvennoy sluzhbe: Brazilskiy opyt (chast 2) [Regulation of conflict of interests in the civil service: Brazilian experience (part 2)]. Voprosy gosudarstvennogo $i$ munitsipalnogo upravleniya, 3, 165-190.

Bonsing, S., Langsted, L. (2013). "Undue” Gifts for Public Employees. An Administrative and Criminal Law and Criminal Justice, 21, 163-184. 